Article

\title{
Key Challenges to Sustainable Humanitarian Supply Chains: Lessons from the COVID-19 Pandemic
}

\author{
Koppiahraj Karuppiah ${ }^{1} \mathbb{D}$, Bathrinath Sankaranarayanan ${ }^{1, * \mathbb{D}}$, Syed Mithun Ali ${ }^{2}$ and Sanjoy Kumar Paul $^{3, * \mathbb{D}}$ \\ 1 Department of Mechanical Engineering, Kalasalingam Academy of Research and Education, Krishnankoil, \\ Tamil Nadu 626126, India; koppiahraj@klu.ac.in \\ 2 Department of Industrial and Production Engineering, Bangladesh University of Engineering and Technology, \\ Dhaka 1000, Bangladesh; mithun@ipe.buet.ac.bd \\ 3 UTS Business School, University of Technology Sydney, Sydney, NSW 2007, Australia \\ * Correspondence: bathri@klu.ac.in (B.S.); sanjoy.paul@uts.edu.au (S.K.P.)
}

\section{check for}

updates

Citation: Karuppiah, K.;

Sankaranarayanan, B.; Ali, S.M.; Paul,

S.K. Key Challenges to Sustainable

Humanitarian Supply Chains:

Lessons from the COVID-19

Pandemic. Sustainability 2021, 13,

5850. https://doi.org/10.3390/

su13115850

\section{Academic Editors:}

Carmen Aviles-Palacios and María Jesús Muñoz-Torres

Received: 25 March 2021

Accepted: 20 May 2021

Published: 22 May 2021

Publisher's Note: MDPI stays neutral with regard to jurisdictional claims in published maps and institutional affiliations.

Copyright: (c) 2021 by the authors. Licensee MDPI, Basel, Switzerland. This article is an open access article distributed under the terms and conditions of the Creative Commons Attribution (CC BY) license (https:// creativecommons.org/licenses/by/ $4.0 /$ )
Abstract: COVID-19 has had a major impact on health, economic, social, and industrial activities. It has disrupted supply chain management and affected the movement of essential supplies to a large extent. This study aims to identify and evaluate the challenges hampering sustainable humanitarian supply chain management (SHSCM). Twenty critical challenges to SHSCM are identified using a comprehensive literature review, and three strategies were developed. The challenges and strategies were verified using expert input. The challenges were evaluated using the neutrosophic analytic hierarchical process (AHP) method. The neutrosophic TODIM (an acronym in Portuguese for interactive multicriteria decision making) method was then used to select the best strategy. The findings reveal that facility location problems, short lead times for emergency supplies, spread of rumors, rapid emergence of new clusters, and doubt concerning the available remedy are five critical challenges in SHSCM during COVID-19. Public-private partnerships are identified as the best strategy in SHSCM. Finally, this paper discusses the implications to sustainable development goals in the post-COVID-19 pandemic era.

Keywords: COVID-19; neutrosophic AHP; TODIM; sustainable HSCM; public-private partnership

\section{Introduction}

Disasters occurring across the world pose a severe threat to human society. Disasters may be natural (heavy rainfall, avalanches, earthquakes) or human made (industrial accidents, chemical leakages, building collapses) in nature [1]. During and after the disaster, the provision of relief and recovery materials lowers victims' suffering. In such a situation, the supply chain network plays a crucial role. Providing the "right materials" in the "right quantity" to the "right people" at the "right time" is the intention of typical supply chain management (SCM) [2]. It is applicable for both commercial and humanitarian SCM (HSCM). In comparison with commercial supply chain management, the number of challenges in HSCM is greater [3]. This is because HSCM is carried out under damaged infrastructure, such as limited energy resources and limited transport connectivity, working in coalition with multiple stakeholders involved in the relief activities, governmental interventions, and the final beneficiaries. From this, it may be well understood that HSCM operates in a more complex and challenging environment [4]. Furthermore, it is important that HSCM activities meet the triple bottom line (TBL) concept, i.e., addressing economic, environmental, and social concerns. The TBL concept is aligned with the sustainability concept. Hence, it is necessary to carry out sustainable HSCM (SHSCM) activities. The organizations involved in relief activities are predominantly classified under three sections, namely bodies working under the United Nations (World Health Organization, Geneva, Switzerland), international organizations (International Committee of Red Cross, Geneva, Switzerland), and nongovernmental organizations (NGOs) (Doctors Without Borders, 
Geneva, Switzerland). Disaster management is a set of operational activities and administrative decisions related to various disasters at all levels [5]. HSCM plays an integral role in disaster management. HSCM needs to be sustainable economically, environmentally, and socially; only then will HSCM meet the intended purpose of delivering medical essentials on time. Hence, SHSCM is critical in disaster management. Furthermore, SHSCM helps in meeting several sustainable development goals (SDGs), such as SDG 3 (good health and wellbeing) and SDG 17 (partnerships for the goals). SDGs are a set of goals proposed by the $\mathrm{UN}$ for the prosperity of people and the planet by the inclusive actions of global nations.

The role of SHSCM in COVID-19 is completely different and remains challenging compared to other more common disasters such as earthquakes, droughts, or floods. As a result, the organizations involved in SHSCM have no earlier experience [5]. Earlier studies have identified and discussed various challenges in SHSCM during a disaster situation. For instance, the study by Sabri et al. (2019) [6] indicated a lack of coordination among the agencies involved in the relief activities as the fundamental challenge in SHSCM. This challenge results in a lack of communication, poor technological infrastructure, lack of administrative personnel, lack of clear policies, ineffective distributing relief material, and stagnation of relief activities [7]. Another critical challenge hampering the efficiency of SHSCM is a difficulty in fundraising [8]. With limited funds, only interim solutions are possible. For longer-term solutions, sufficient funds must be raised. Ozdemir et al. (2020) [9] investigated the blockchain's efficiency in minimizing SHSCM challenges and embarked on introducing new technologies. Another study by Dubey et al. (2019) [10] on the role of big data in organizational assistance revealed that the usage of big data paved the way for swift trust and collaborative performance. A similar study on the adoption of big data by Prasad et al. (2018) [11] emphasized raising awareness among the government and NGOs about how the latest technology mutually benefits each party in SHSCM. Adopting the latest cutting-edge technology greatly helps the functions of SHSCM activities, but such adoption by emerging countries remains a challenge [12]. With limited technological advancement, limited capital support, and limited awareness of technological advancement, developing countries cannot be expected to competently address SHSCM challenges without the intervention of reliable technologies.

Although the concept of SHSCM has been extensively discussed by different literature resources, a study on SHSCM under the COVID-19 situation is urgently needed. This study is critical in this unprecedented situation as delay in the supply of medical essentials results in increased COVID-19 victims. Ensuring timely delivery of medical essentials significantly reduces the number of COVID-19 victims. Additionally, two major gaps exist in current SHSCM research. First, none of the earlier studies on SHSCM has categorized and analyzed challenges in the context of sustainability. The majority of earlier studies identified the challenges and evaluated them without categorization of the challenges under specific groups, such as social, economic, and environmental groups $[13,14]$. Second, previous studies have not evaluated the suitability of some potential strategies in implementing seamless SHSCM activities. Therefore, previous studies have analyzed several challenges without categorization and have not assessed any possible SHSCM activity strategies. Hence, it is essential to address both the gaps in the literature: to categorize the various challenges and to postulate several strategies useful in SHSCM activities. In this study, we seek to fill in the gaps in the research and provide an effective strategy for implementing SHSCM activities during the COVID-19 pandemic. This paper intends to find the answers to the following questions:

1. What are the critical challenges that need to be addressed at the earliest time to execute SHSCM activities during and after the COVID-19 pandemic?

2. Which strategy would best serve SHSCM activities?

To answer the above research questions, a combination of AHP (analytic hierarchical process) and TODIM (an acronym in Portuguese for interactive and multicriteria decision making) in a neutrosophic context is used in this study. A neutrosophic set has three membership functions representing the truth membership function, indeterminacy mem- 
bership function, and falsity membership function. Here, neutrosophic AHP is used for calculating the weights of the challenges to SHSCM. Furthermore, neutrosophic TODIM is used for ranking the strategies. In this study, the neutrosophic set is preferred over the fuzzy set and the intuitionistic fuzzy set for several reasons. The fuzzy set considers only a truth membership degree, whereas the intuitionistic fuzzy set considers both truth and falsity degrees. However, both fail to consider indeterminacy. To deal with this drawback, Smarandache (2005) [13] introduced neutrosophic sets which consider truth, indeterminacy, and falsity degrees together to represent uncertain and/or inconsistent information. Thus, neutrosophic sets are a better representation of reality. The TODIM method, introduced by Gomes \& Lima (1992) [14], is vital for two reasons. First, it combines qualitative and quantitative data to select a better strategy in handling SHSCM during COVID-19. Second, the TODIM method analyses the risks using prospect theory [15]. The AHP method is generally used for weight calculation over other methods as it involves a pairwise comparison of the challenges under consideration. Pairwise comparisons between the challenges detail the nature and significance of these challenges [16].

This research contributes to the literature in several ways. First, this study proposes challenges to SHSCM. This study is expected to provide better insights to manage COVID-19 or other natural pandemics sustainably. Second, the study outcomes can help government and private organizations better understand SHSCM during and after the COVID-19 pandemic. Third, this study is the first of its kind using a combination of AHP and TODIM in a neutrosophic context in the domain of SHSCM. The study's outcome reveals the weight importance of each challenge in SHSCM and rank the strategies to help manage SHSCM activities. This can benefit the organizations and government agencies involved in the SHSCM network.

The paper's structure is as follows: Section 2 outlines the concept of SHSCM and the challenges in SHSCM. Section 3 discusses the research methodology used in the study. Section 4 illustrates the application of the proposed research methodology. Section 5 discusses the results obtained in the study. Finally, Section 5 concludes the study with limitations and the future scope for research.

\section{Literature Review}

\subsection{Sustainable Humanitarian Supply Chain Management (SHSCM)}

The supply chain network acts as a link between the production sector and the end user in the business context. A supply chain network's goal is to deliver the right product in the right quantity to the right customer at the right time [17]. Likewise, the movement of goods/materials involved in relief activities is known as humanitarian supply chain management (HSCM) [18]. According to the United Nations International Strategy for Disaster Reduction (UNISDR), a disaster is defined as "a serious disruption of the functioning of a community involving human, material and economic loss, which exceeds the ability of the affected community to cope using its resources" [19]. Similarly, the International Federation of Red Cross and Red Crescent Societies (IFRC) defines disaster as a sudden event that seriously disrupts society's functioning with loss of human life and resources beyond the ability to recover [20]. HSCM intends to meet the affected people's needs by efficiently using the given resources during and after the disaster [21]. Additionally, HSCM seeks to mitigate the suffering of the affected population to the fullest extent possible. There is no defined form of HSCM [22]. However, both the government and non-governmental organizations (NGOs) are the primary parties involved. The government holds the essential control with its political and economic power [23]. A conventional HSCM focuses only on lessening the suffering of people, i.e., the social dimension only. However, emphasizing the economic and environmental dimensions provides better stability to HSCM activities. In this regard, the preference for sustainable HSCM (SHSCM) is useful since it covers all three of the critical pillars: economic, environmental, and social dimensions. This study focuses on the importance of SHSCM in regard to the unprecedented COVID-19 pandemic. 
Disaster management is comprised of four phases: mitigation, preparedness, response, and rehabilitation [24]. The mitigation phase involves applying precautionary steps aimed at preventing or minimizing the impact of a disaster. With COVID-19, precautionary steps include maintaining social distance, wearing masks and gloves, and routine sanitization. The preparedness phase includes maintaining sufficient stock of essential and emergency materials. In the COVID-19 scenario, preparedness includes having a sufficient ventilators and medical equipment. The response phase is the deployment of life-saving emergency services. This phase includes the establishment of special wards for COVID-19 patients and treatment. Finally, rehabilitation refers to long term action taken for the wellbeing of the affected community. In the COVID-19 pandemic, post-COVID treatment and rehabilitation centers have been established. Several studies indicate that the last two phases, i.e., response and rehabilitation, are critical compared to the first two phases (mitigation and preparedness). Although extensive research is carried out in HSCM [25,26], the problems related to SHSCM remain a challenge due to the complex nature of the disaster. In summary, an SHSCM needs to encompass a holistic nature of the disaster. In this view, this study intends to identify various challenges involved in SHSCM during COVID-19.

\subsection{Proposed Challenges to SHSCM}

SHSCM is unique and operates under difficult circumstances. In commercial supply chain management, the main aim is to gain profit for the stakeholder(s) and deliver products to the customers, while SHSCM intends to save lives and reduce suffering [27]. The actual challenge involved in SHSCM depends on the nature of the disaster and its location. A large number of local and international NGOs can be seen at the place of disaster. Under such an environment, challenges arise regarding prioritizing objectives and settings, as many stakeholders are involved [28]. The stakeholders may have conflicting interests and objectives. This leads to the absence of a centralized, integrated management and planning system. The lack of a comprehensive approach often leads to multiple stakeholders' parallel acts that may result in overlap or interference of relief activities [29]. In addition, with no lead time and no reliable transportation, the complexity of the challenges becomes multifold. Difficulties in procurement, the supply and demand equation, supply strategy, supplier location, and transportation choice further worsen the existing challenges.

Different disasters exhibit a variety of characteristics; each disaster demands a different approach based on its nature, the number of people affected, and its location. Hence, there is no proper index for measuring the success of SHSCM [30]. According to Das (2016) [31], SHSCM tends to be unstable, inclined toward political and military influence, and inefficient due to a lack of joint planning and interorganizational collaboration. Seifert et al. (2018) [32] carried out a study on the challenges in SHSCM in responding to refugees and suggested a lack of technological advancement as the main challenge. Another study by Sahebi et al. (2017) [33] regarding disaster management in the Iranian context revealed cultural, managerial, and educational barriers in providing seamless relief activities. A similar study by Petrudi et al. (2020) [34] that analyzed SHSCM challenges indicates inexperience of the top management in handling the disaster and lack of skilled workers as the major hindrances. Ozdemir et al. (2020) [9] analyzed the role of blockchain in minimizing the challenges in SHSCM. The study's findings emphasized the incorporation of advanced technology, as it acts as a tool to execute SHSCM activities. Based on the literature review, this study identified several challenges that appear to lower or affect the efficiency of SHSCM. These identified challenges are given in Table 1. 
Table 1. Challenges in sustainable humanitarian supply chain management (SHSCM).

\begin{tabular}{|c|c|c|c|c|}
\hline $\begin{array}{l}\text { S. } \\
\text { No }\end{array}$ & Category & Challenges & Explanation & References \\
\hline \multirow{6}{*}{1} & \multirow{6}{*}{ Organizational (C1) } & $\begin{array}{l}\text { Lack of skilled volunteers } \\
\text { and workers (C11) }\end{array}$ & $\begin{array}{l}\text { Insufficient number of paramedic staffs who can } \\
\text { handle the situation efficiently }\end{array}$ & {$[13,14]$} \\
\hline & & $\begin{array}{l}\text { Change of the head of the } \\
\text { monitoring committee (C12) }\end{array}$ & $\begin{array}{l}\text { Often changing the head of the monitoring } \\
\text { committee leads to confusion in proper } \\
\text { information flow }\end{array}$ & {$[14,35]$} \\
\hline & & Lack of coordination (C13) & $\begin{array}{c}\text { Frequent change in the head of the monitoring } \\
\text { committee brings difficulty in establishing } \\
\text { coordination among members of the supply } \\
\text { chain network }\end{array}$ & {$[14,24]$} \\
\hline & & $\begin{array}{l}\text { Lack of division of } \\
\text { works (C14) }\end{array}$ & $\begin{array}{l}\text { Difficulty in assigning tasks causes confusion and } \\
\text { may impact the expected outcome }\end{array}$ & {$[13,36]$} \\
\hline & & $\begin{array}{c}\text { Lack of experts for pandemic } \\
\text { management }(\mathrm{C} 15)\end{array}$ & $\begin{array}{l}\text { Appointment of new personnel struggles in } \\
\text { handling and decision making }\end{array}$ & {$[35,37]$} \\
\hline & & $\begin{array}{l}\text { Doubt concerning the } \\
\text { available remedy (C21) }\end{array}$ & $\begin{array}{l}\text { Fear about the efficacy of the available remedy } \\
\text { prevents the public from taking the drug }\end{array}$ & This paper \\
\hline \multirow[t]{4}{*}{2} & \multirow[t]{4}{*}{ Social (C2) } & $\begin{array}{l}\text { Influence of socioeconomic } \\
\text { and political condition of the } \\
\text { region }(\mathrm{C} 22)\end{array}$ & $\begin{array}{c}\text { Local condition of the region or the country } \\
\text { influences the efficiency of the supply } \\
\text { chain network }\end{array}$ & {$[33,37]$} \\
\hline & & $\begin{array}{l}\text { Lack of awareness among } \\
\text { people (C23) }\end{array}$ & $\begin{array}{l}\text { Lack of knowledge of humanitarian } \\
\text { organizations and activities }\end{array}$ & {$[14,29]$} \\
\hline & & Spread of rumors (C24) & $\begin{array}{c}\text { Misleading information creates panic among } \\
\text { the public }\end{array}$ & {$[24,38]$} \\
\hline & & $\begin{array}{l}\text { Limited information and } \\
\text { telecommunication } \\
\text { infrastructure }(\mathrm{C} 31)\end{array}$ & $\begin{array}{l}\text { The shortage of advanced information } \\
\text { communication system amplifies the impact of } \\
\text { the situation }\end{array}$ & {$[24,33,39]$} \\
\hline \multirow[t]{3}{*}{3} & \multirow[t]{3}{*}{ Technical (C3) } & $\begin{array}{l}\text { Poor adoption of } \\
\text { technologies (C32) }\end{array}$ & $\begin{array}{l}\text { The nonusage of technologies like GPS and } \\
\text { information systems makes it difficult to track the } \\
\text { relief material's movement }\end{array}$ & {$[24,29]$} \\
\hline & & $\begin{array}{l}\text { Short lead time for } \\
\text { emergency supplies (C33) }\end{array}$ & $\begin{array}{l}\text { Increased level of demand adds pressure on the } \\
\text { manufacturing units }\end{array}$ & {$[13,40]$} \\
\hline & & $\begin{array}{l}\text { Inadequate transport } \\
\text { infrastructure (C34) }\end{array}$ & $\begin{array}{l}\text { Insufficient number of harbors, roads, and } \\
\text { airports restricts the import and distribution of } \\
\text { the relief material }\end{array}$ & {$[37,39]$} \\
\hline \multirow[t]{4}{*}{4} & \multirow[t]{4}{*}{ Economical (C4) } & $\begin{array}{l}\text { Insufficient fund in handling } \\
\text { the pandemic }(\mathrm{C} 41)\end{array}$ & $\begin{array}{l}\text { Limited fund restricts the procurement of } \\
\text { necessary equipment }\end{array}$ & {$[14,35]$} \\
\hline & & $\begin{array}{l}\text { Facility location } \\
\text { problem (C42) }\end{array}$ & $\begin{array}{l}\text { Shortage of warehouse and cold storage system } \\
\text { may hamper the flow of relief materials }\end{array}$ & {$[14,35]$} \\
\hline & & $\begin{array}{l}\text { Nonavailability of suitable } \\
\text { transport infrastructure (C43) }\end{array}$ & $\begin{array}{c}\text { The absence of suitable transport systems like } \\
\text { helicopters and heavy trucks delays the delivery } \\
\text { of relief materials }\end{array}$ & {$[13,37]$} \\
\hline & & $\begin{array}{l}\text { Shortage of precautionary } \\
\text { materials (C44) }\end{array}$ & $\begin{array}{l}\text { The ever-increasing number of active cases leads } \\
\text { to the shortage of precautionary materials }\end{array}$ & {$[24,37]$} \\
\hline \multirow{3}{*}{5} & \multirow{3}{*}{ Environmental (C5) } & Uncertainty in demand (C51) & $\begin{array}{l}\text { Difficulty in calculating the exact number of the } \\
\text { affected population }\end{array}$ & {$[33,37]$} \\
\hline & & $\begin{array}{l}\text { Rapid emergence of new } \\
\text { clusters (C52) }\end{array}$ & $\begin{array}{l}\text { The emergence of a new cluster creates new } \\
\text { demand and makes it difficult for delivery }\end{array}$ & {$[33,35]$} \\
\hline & & $\begin{array}{l}\text { Communication barriers (i.e., } \\
\text { different languages and } \\
\text { cultures) (C53) }\end{array}$ & $\begin{array}{l}\text { The existence of different languages and cultures } \\
\text { pose a threat to the delivery of relief material }\end{array}$ & {$[13,41]$} \\
\hline
\end{tabular}

\subsection{Existing Methods}

A review of extant literature reveals that several multicriteria decision-making (MCDM) methods have been used in analyzing the performance of SHSCM. Sharma et al. (2020) [2] utilized the stepwise weight assessment ratio analysis (SWARA) method to analyze the significant factors affecting SHSCM during the COVID-19 pandemic situation in the Indian context. An integrated method consisting of an intuitionistic fuzzy decision-making trial 
and evaluation laboratory (DEMATEL) and analytic network process (ANP) was used by Ozdemir et al. (2020) [9] to analyze the contribution of blockchain in SHSCM. Similarly, Petrudi et al. (2020) [34] applied fuzzy interpretive structural modeling (FISM) to analyze the challenges involved in SHSCM. Sahebi et al. (2017) [33] used the fuzzy best-worst method (BWM) for analyzing the barriers in SHSCM. Agarwal et al. (2020) [42] used an integrated approach comprising fuzzy Delphi (FD), interpretive structural modeling (ISM), and matrices impacts croises multiplication applique a un classement (MICMAC, crossimpact matrix multiplication) analysis for evaluating the enablers of SHSCM. In another study, Agarwal et al. (2020) [43] used a combined fuzzy stepwise weight assessment ratio analysis (SWARA) and a fuzzy weighted aggregated sum product assessment (WASPAS) for analyzing barriers in SHSCM. From the above discussion, it is evident that an analysis of SHSCM using MCDM methods under a neutrosophic context has not been carried out. As such, this study proposes a framework for evaluating the challenges involved in SHSCM using AHP and TODIM in a neutrosophic set context.

\subsection{Proposed Method Background}

Many research works have been carried out with the individual application of AHP and TODIM for solving various problems in SHSCM. The AHP method was first proposed by Saaty (1980) [44] for analyzing the multiple challenges in agriculture. Later on, the AHP method was used in other areas like project management [45], landfill site selection [46], and flood susceptibility mapping [47], where multiple challenges need to be analyzed. While the AHP method is widely preferred, it fails to account for ambiguity in human judgment. To overcome this drawback, Zadeh (1965) [48] introduced the concept of fuzzy set theory which considers the truth membership function and helps overcome imprecision. However, the fuzzy extension fails to address indeterminacy. Hence, the neutrosophic set, offered by Smarandache (2005) [13], offers a three-membership function representing truth, indeterminacy, and falsity membership functions. By incorporating a neutrosophic set with the AHP method, various studies have been carried in different areas. For instance, Kahraman et al. (2018) [49] used neutrosophic AHP for selecting the best outsourcing agency for legal works. In another work, Salgado et al. (2020) [50] analyzed various aspects of Ecuador's adoption process.

Next, the TODIM method introduced by Gomes and Lima (1992) [14] is widely preferred for two reasons. First, it combines qualitative and quantitative data to select a better strategy. Second, the TODIM method analyzes the risks or challenges using prospect theory. In TODIM, challenges are compared with strategies, and based on their comparison, the better strategy is identified. Several kinds of research have been carried out using neutrosophic TODIM. Fan et al. (2020) [51] applied neutrosophic TODIM for carrying out a failure mode and effect analysis (FMEA) in the steel industry. Similarly, Long et al. (2020) [52] used neutrosophic TODIM to select restoration methods in a Chinese architectural context.

\subsection{Research Gaps and Contributions}

A study by Shareef et al. (2020) [53] explored big data's role in assisting the sustainable humanitarian supply chain during disasters; their findings reveal the potential impact of big data. However, due to their advancements in technologies, developed countries can carry out sustainable humanitarian supply chain activities with ease compared to developing countries [54]. To analyze challenges in HSCM, Petrudi et al. (2020) [34] used fuzzy interpretive structural modeling (FISM), and Sahebi et al. (2017) [33] used the bestworst method. From the above information, it is apparent that a study addressing the challenges of SHSCM during COVID-19 is needed. Keeping this in mind, this study intends to attain some goals. First, a study considering the challenges faced in SHSCM during the unprecedented COVID-19 pandemic situation has not been carried out. Analyzing the challenges of SHSCM during COVID-19 is of substantial importance. It may provide valuable input for organizations involved in humanitarian activities, and it may result in 
the faster movement of relief materials to needy populations. Such research can be vital if it is carried out in the context of developing countries, since they face more difficulty than developed countries in managing SHSCM activities [55]. Analyzing the challenges of SHSCM using a hybrid MCDM technique is also uncommon.

This study intends to fill research gaps by developing an integrated research framework that provides valuable information about SHSCM activities in the Indian context. The research methodology used in the work is a combination of AHP and TODIM under a neutrosophic set. The study's outcome reveals the weight importance of each challenge in SHSCM and rank the strategies to help manage SHSCM activities. This benefits the organizations and government agencies involved in the SHSCM network.

\section{Methodology}

This section discusses the methodological steps used in this study and the application of the methodology. Figure 1 illustrates the sequence of the methodology. Initially, the analytic hierarchical process (AHP) is used to determine the weight of the challenges in SHSCM. Next, TODIM, a multicriteria decision-making method under a neutrosophic environment, is used to rank the strategies for SHSCM in the COVID-19 situation.

\section{Stage 1: Identification and finalization of SHSCM challenges and strategies during COVID-19}

Problem defirition and identification of research gap through literature review

Developing a questionnaire with a list of identified HSCM challenges Requesting the experts to give their opinion on the given challenges
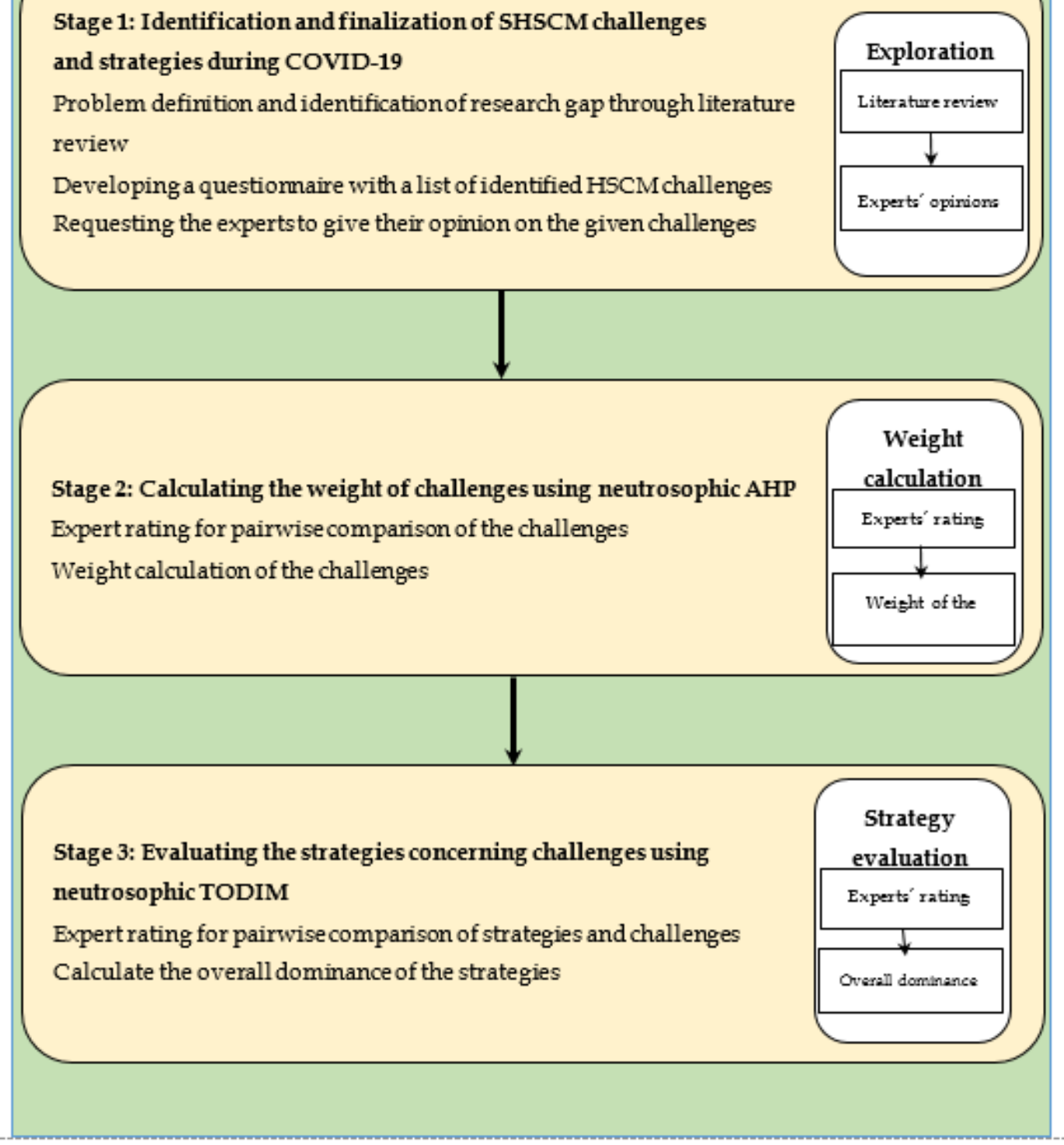

Figure 1. Proposed methodological framework. 


\subsection{Methods Used}

Here, the methods used for evaluating the challenges and strategies are explained.

\subsubsection{AHP}

The AHP method developed by Saaty (1980) [44] is used to determine the weight and rank of the factors under consideration. AHP is based on four principles: homogeneity, expectations, reciprocity, and dependency. The steps involved in AHP are as follows:

(a) Defining the challenges

In this step, the challenges that must be analyzed are defined. SHSCM is always a crucial operation as it is generally carried out with many difficulties. During COVID-19, the situation is worse as more challenges act as a hindrance.

(b) Pairwise comparison

During this stage, a response sheet comprising all the challenges under consideration was given to the experts. Then, the experts were asked to rate the influence of the challenges against each other in their perspective using the scale given in Table 2. In general, more experts are approached for pairwise comparison. To summarize the experts' responses, the average of the experts' responses was taken into consideration. Consider a matrix $A$ of size $m \times n$ with $m$ alternatives and $n$ challenges. The matrix $A$ is given as

$$
A=\left[\begin{array}{cccc}
a_{11} & \cdots & \cdots & a_{1 n} \\
\vdots & \ddots & \cdots & \vdots \\
\vdots & \cdots & \ddots & \vdots \\
a_{m 1} & \cdots & \cdots & a_{m n}
\end{array}\right]
$$

where $a_{i j}=$ superiority of alternative $i$ over alternative $j$.

Table 2. Linguistic terms and triangular neutrosophic numbers.

\begin{tabular}{ccc}
\hline Saaty Scale & Definition & Neutrosophic Triangular Scale \\
\hline 1 & No influential (N) & $\widetilde{1}=((1,1,1) ; 0.50,0.50,0.50)$ \\
3 & Lightly influential (L) & $\widetilde{3}=((2,3,4) ; 0.30,0.75,0.70)$ \\
5 & Strongly influential (S) & $\widetilde{5}=((4,5,6) ; 0.80,0.15,0.20)$ \\
7 & Very strongly influential (V) & $\widetilde{7}=((6,7,8) ; 0.90,0.10,0.10)$ \\
9 & Absolutely influential (A) & $\widetilde{9}=((9,9,9) ; 1.00,1.00,1.00)$ \\
\hline
\end{tabular}

The neutrosophic triangular scale value is converted into a single crisp value by using Equation (2).

$$
S\left(a_{i j}\right)=\frac{1}{8}\left[a_{1}+b_{1}+c_{1}\right] \times\left(2+\alpha_{\widetilde{a}}-\theta_{\widetilde{a}}-\beta_{\widetilde{a}}\right)
$$

\subsubsection{TODIM}

TODIM is a Portuguese term indicating interactive and multiple attribute decision making, first introduced by [14]. The TODIM method was based on prospect theory [56]. This method measures the dominance degree of each alternative over the other alternatives using the overall value. The TODIM method is used in areas such as product selection [57], portfolio allocation [58], and project manager selection [59]. The following are the steps involved in the TODIM method:

(c) Establishing a decision-making matrix 
Consider $m$ strategies and $n$ challenges; the decision matrix is formed based on the performance of strategy $i$ against challenge $j$ as follows:

$$
X=\left[\begin{array}{llll}
x_{11} & x_{12} & x_{13} & x_{1 n} \\
x_{21} & x_{22} & x_{23} & x_{2 n} \\
x_{31} & x_{32} & x_{33} & x_{3 n} \\
x_{m 1} & x_{m 2} & x_{m 3} & x_{m n}
\end{array}\right],(i=1,2, . ., m ; j=1,2, . ., n)
$$

where $x_{i j}=$ performance of strategy $i$ against challenge $j$.

(d) Normalization of the decision matrix

The challenges are determined and normalized using Equations (4) and (5):

$$
\begin{aligned}
& r_{i j}^{*}=\frac{r_{i j}}{\sum_{i=1}^{m} r_{i j}} \\
& r_{i j}^{*}=\frac{\frac{1}{r_{i j}}}{\sum_{i=1}^{m} \frac{1}{r_{i j}}}
\end{aligned}
$$

where $r_{i j}^{*}=$ normalized elements of the decision matrix.

(e) Determining the relative weight of challenges

The weight of the challenges obtained using AHP is divided by the challenges' reference weight, i.e., the largest weight of the challenges. The relative weight of the challenges is obtained using Equation (6):

$$
\widetilde{w}=\frac{w_{j}}{\hat{w}}
$$

where $\widetilde{w}=$ relative weight of the challenges; $w_{j}=$ the weight of the challenge; and $\hat{w}=$ reference weight.

(f) Dominance degree

The dominance degree of each strategy relative to other strategies is calculated using Equation (7):

$$
\phi_{j}\left(S_{i}, S_{j}\right)=\left\{\begin{array}{cl}
-\frac{1}{\theta} \sqrt{\frac{\sum_{j=1}^{n} \widetilde{w}_{j}\left|r_{i j}^{*}-r_{j i}^{*}\right|}{\widetilde{w}_{j}}} & \text { if }\left(r_{i j}^{*}-r_{j i}^{*}\right)<0 \\
0 & \text { if }\left(r_{i j}^{*}-r_{j i}^{*}\right)=0 \\
\sqrt{\frac{w_{j}\left(r_{i j}^{*}-r_{j i}^{*}\right)}{\sum_{j=1}^{n} \widetilde{w}_{j}}} & \text { if }\left(r_{i j}^{*}-r_{j i}^{*}\right)>0
\end{array}\right.
$$

where $\theta$ is the attenuation factor of the losses and is set equal to 1 in this work.

(g) Overall dominance degree

The overall dominance degree of each strategy is calculated using Equation (8):

$$
\zeta_{i}=\frac{\delta_{i}-\min \delta_{i}}{\max \delta_{i}-\min \delta_{i}}, i=1, . ., m
$$

(h) Ranking of strategies

The overall value of each strategy determines the ranking of the strategies. The larger the value of the strategy, the more desirable the strategy. 


\subsection{An Application of the Proposed Framework}

According to a World Health Organization (WHO) report, globally, 79,673,754 persons were infected by COVID-19, resulting in 1,761,381 deaths [60]. This unprecedented situation has affected all global countries, including both developed and developing countries, negatively. Without the vaccine and clear data on the transmission of the virus, the world's superpowers and other developing countries are facing difficulty managing the situation. However, global countries are making their best efforts in containing transmission. Precautionary steps, such as social distancing, wearing masks and gloves, and frequent sanitation of the hands, are suggested and followed to contain the spread. Since the vaccine has been developed, there are several challenges in ensuring the timely delivery of the vaccine [61]. Therefore, there is a need to evaluate the challenges in SHSCM. In this regard, this study's emphasis is on exploring and evaluating the challenges of SHSCM. For this, an expert team consisting of 10 experts was formed. The experts in the team have sufficient knowledge of SHSCM. The basic profile of the experts is given in Table 3.

Table 3. Profile of the experts.

\begin{tabular}{ccc}
\hline Variables & Number of Experts & Percentage of Experts \\
Female & Gender: & \\
Male & 4 & $40 \%$ \\
& 6 & $60 \%$ \\
$31-40$ years & Age: & $50 \%$ \\
$41-50$ years & 5 & $50 \%$ \\
& 5 & $30 \%$ \\
Graduation & Educational qualification: & $40 \%$ \\
Postgraduation & 3 & $30 \%$ \\
Doctorate & 4 & \\
& 3 & $20 \%$ \\
Less than 10 years & Work experience: & $40 \%$ \\
10-15 years & 2 & $20 \%$ \\
16-20 years & 4 & $20 \%$ \\
21-25 years & 2 & $30 \%$ \\
& 2 & $20 \%$ \\
Procurement manager & Expertise: & $30 \%$ \\
Supply chain supervisor & 3 & $20 \%$ \\
Supplier & 2 &
\end{tabular}

\subsubsection{Identification and Finalization of Challenges}

For identifying the challenges of SHSCM, an extant literature review was performed. The literature referred to for the study was collected from science databases, such as Science Direct, Google Scholar, Web of Science, and Taylor and Francis. To collect literature, the following keywords and Boolean operators were used: COVID-19, COVID-19 management in developing countries AND developed countries, Challenges OR barriers in managing COVID-19, Barriers in sustainable HSCM AND problem in sustainable HSCM, COVID-19 AND logistics, COVID-19 AND supply chain, and coronavirus AND its impact. From the literature review, 20 challenges in SHSCM were identified. However, to confirm the appropriateness of the identified challenges to SHSCM, expert opinions on these challenges were sought. For this, a questionnaire (Table A1 of Appendix A) consisting of the identified challenges was given to the experts (Table 3). The questionnaire is a YES/NO type. The experts were requested to give "YES" when they found the given challenge as appropriate to SHSCM and "NO" when they found the given challenge as inappropriate. The experts found all the identified challenges as appropriate to SHSCM. Furthermore, the experts were also convinced of the strategies chosen for handling SHSCM during COVID-19. The three strategies are S1-a public-private partnership; S2-complete privatization; S3-completely government controlled. 


\subsubsection{Evaluation of Challenges and Selection of Best Strategy}

After confirming the challenges and strategies, the evaluation phase was carried out based on the experts' opinions. The experts were asked to rate the significance of challenges using pairwise comparisons. For this, a response sheet comprising of all the challenges (Table 1) along with scale (Table 2) was given to the experts. The experts' geometric mean responses are given in Table A2 of Appendix A. The experts' linguistic responses are converted into neutrosophic values and then converted into crisp values using Equation (2) and given in Table A3 of Appendix A. The crisp value is then normalized and is given in Table 4 of Appendix A. Then, the weight of the challenges is calculated and given in Table 4.

Table 4. Weight and relative weight of the challenges.

\begin{tabular}{cccc}
\hline Challenges & Weight & Rank (Weight) & Relative Weight \\
\hline C11 & 0.0374 & 14 & 0.51 \\
C12 & 0.0651 & 6 & 0.88 \\
C13 & 0.0391 & 13 & 0.53 \\
C14 & 0.0475 & 10 & 0.65 \\
C15 & 0.0629 & 7 & 0.85 \\
C21 & 5 & 0.90 \\
C22 & 0.0665 & 9 & 0.68 \\
C23 & 0.0505 & 11 & 0.58 \\
C24 & 0.0428 & 3 & 0.98 \\
C31 & 18 & 0.45 \\
C32 & 0.0726 & 12 & 0.58 \\
C33 & 0.0333 & 2 & 0.99 \\
C34 & 0.0426 & 15 & 0.49 \\
C41 & 0.0728 & 8 & 0.77 \\
C42 & 0.0359 & 1 & 1.00 \\
C43 & 0.0569 & 20 & 0.38 \\
C44 & 0.0737 & 17 & 0.46 \\
C51 & 0.0283 & 19 & 0.41 \\
C52 & 0.0340 & 4 & 0.98 \\
C53 & 0.0301 & 16 & 0.48 \\
Sum & 0.0725 & & 13.57 \\
\hline
\end{tabular}

Next, to find a better strategy during COVID-19, a comparison is made between the challenges and strategies using the neutrosophic values given in Table 2. The comparison made is given in Table A5 of Appendix B. The neutrosophic values are converted into crisp values using Equation (2) and are given in Table A6 of Appendix B. Then, the crisp values are normalized using Equations (4) and (5) and are given in Table A7 of Appendix B. The relative weights of the challenges are calculated using Equation (6). The relative weights are given in Table 4 and Figure 2. Then, each strategy's dominance degree is calculated using Equation (7) against the challenges and given in Tables A8-A10 of Appendix C. The overall dominance degree of each strategy is calculated using Equation (8) and is given in Table 5.

Table 5. Overall dominance degree $\left(\xi_{i}\right)$ of the strategies.

\begin{tabular}{cc}
\hline Overall Dominance Degree & Strategies \\
\hline$S_{1}$ & 1 \\
$S_{2}$ & 0 \\
$S_{3}$ & 0.90 \\
\hline
\end{tabular}




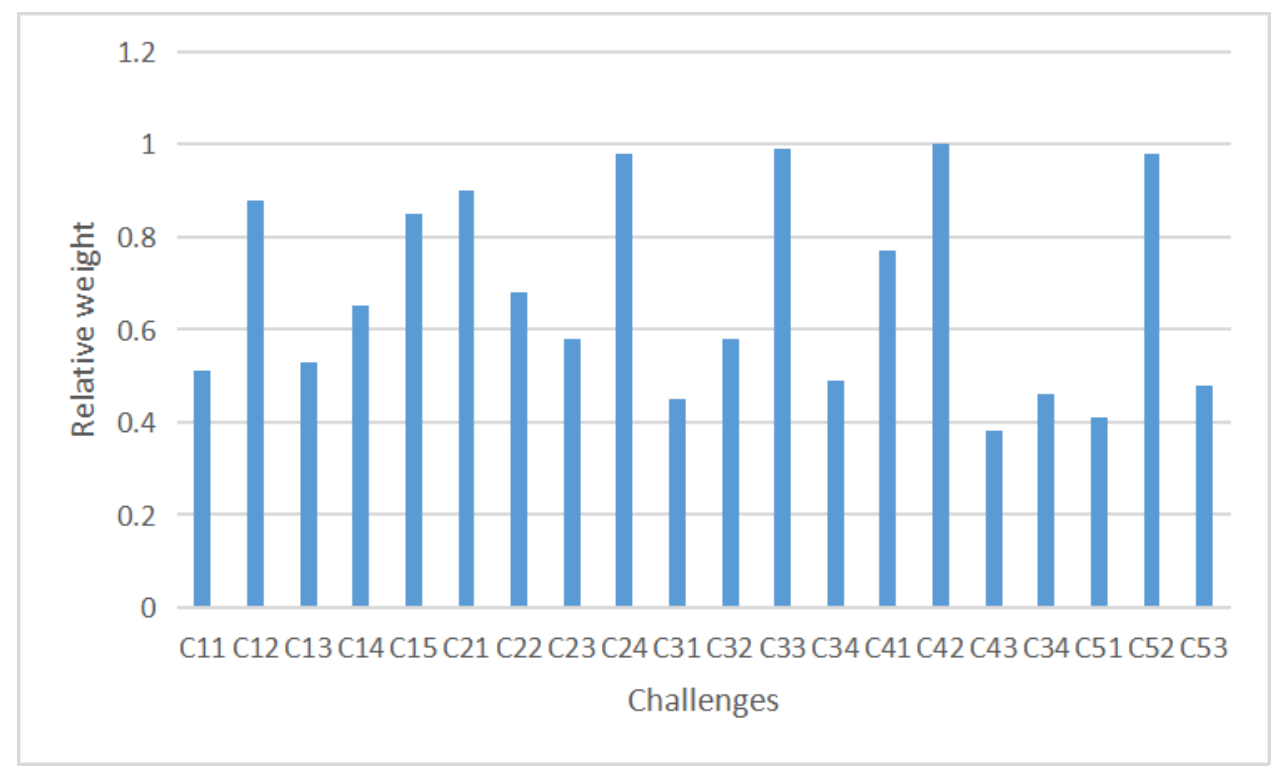

Figure 2. Relative weights of the challenges.

\section{Results and Discussion}

\subsection{Weights of the Challenges}

Based on the experts' views, each challenge's weight is calculated by making a pairwise comparison. The calculated weight of the challenges is given in Table 4. According to Table 4, challenge C42 (facility location problem) has the highest weight (0.0737) among the challenges. This indicates that challenge C42 remains a major problem in SHSCM during COVID-19. Next, challenge C33 (short lead time for emergency supplies), with a weight of 0.0728, is the second major problem. Then, challenges C24 (spread of rumors), C52 (rapid emergence of new clusters), and C21 (doubt concerning the available remedy), with weights of $0.0726,0.0725$, and 0.0665 , respectively, also need to be addressed in SHSCM.

The challenge $\mathrm{C} 42$ needs special attention as the vaccine that is being developed needs a special cold storage system. According to a study by Crommelin et al. (2020) [62], freeze drying and a storage temperature of $2-8{ }^{\circ} \mathrm{C}$ is required during the transportation and storage of the vaccine that is being developed. Though a complete, reliable vaccine has been developed, the general belief is that it needs a special storage system. The establishment of cold storage needs several technical forms of assistance. With minimal technological infrastructure and support, developing countries such as India face difficulties establishing a cold storage system compared to developed countries [63]. In short, to combat COVID-19, countries need to have an efficient cold storage system. Then, the challenge C33 appears to be another important challenge in tackling COVID-19. As the nature and behavior of the virus causing COVID-19 has not been completely revealed, there is a delay in vaccine development [64]. Further, the incubation time of the virus also has not been exactly determined. Together, these complexities remain a major hindrance in vaccine development. In minimizing the victims of COVID-19, emergency supplies like ventilators and nebulizers are widely used. However, the exponentially rising number of COVID-19 cases has resulted in a shortage of ventilators [65]. Additionally, there is a shortage of other emergency supplies, such as pulse oximeters, personal protective equipment (PPE), and intensive care unit (ICU) space in hospitals. Such a shortage of emergency supplies proves to be lethal in COVID-19 management [66].

Next, challenge C24, the spread of rumors, needs to be addressed. Rumors and misinformation are spread regarding the nature and impact of COVID-19; moreover, this information is often false and misleading. False information on COVID-19 leads to carelessness and recklessness among the general public. A lethargic attitude of the public results in an increased number of patients. An increase in the number of patients creates a shortage of emergency medical services for older people and people with comorbidities. This was 
supported by a study by Huda et al. (2020) [38], which states that public rumors create chaos and lead to disaster. It is essential to monitor false information being circulated on social media. Further, the government must take stringent action against those involved in rumor spreading. The government must also take the necessary steps in spreading the exact nature and impact of COVID-19 among the public through mass media communication, such as television and newspapers. The spread of rumors may lead to the emergence of a new cluster. In COVID-19, the virus spread began as an epidemic and later reached pandemic status. Initially, the information about COVID-19 was less known and was taken lightly. Now, with extensive studies, the data on COVID-19 has been revealed. However, the carelessness of society accelerates the spread of the disease. The emergence of a new cluster is a serious issue as it isolates that region from the world. Such incidences may bring the transportation of essential commodities to a halt. Furthermore, the socioeconomic activities of the new cluster could be badly affected. As considered in this study, the first case of COVID-19 in India was reported in Kerala [67]. Soon, the borders of Kerala were closed. It affected the socioeconomical activities of Kerala as its economy was largely based on the tourism sector. When a new cluster emerges, more emphasis is given to the new cluster. More relief material is supplied to the new cluster under such a situation, which calls into question whether the distribution of needed supplies is fair and equal.

Challenge C21 remains an important problem in the supply of relief materials. In the case of COVID-19 the race for the vaccine is still open. Many global pharmaceutical industries are working to come up with an effective, reliable, and robust vaccine. However, with short lead times and high demand, the pharmaceutical industries are struggling to develop a robust vaccine. Furthermore, the developed vaccines' trial runs induce fear among the public and raise the efficacy of the vaccines. In some trial runs, volunteers who took the developed vaccines were exposed to some serious allergies and side effects [68]. Studies by Bennet et al. (2020) [69] and Krause et al. (2020) [70] state that the development of allergies and side effects are the results of developing vaccines in a hurry. The studies also state that on average, $2-4$ years is required to develop a vaccine free from side effects and allergies. Stages such as the initial exploratory study, preclinical study, and clinical study in a three-phase manner are followed in vaccine development. Apart from these challenges, other challenges, such as communication barriers (i.e., different languages and cultures), nonavailability of suitable transport infrastructure, inadequate transport infrastructure, lack of coordination, and lack of skilled volunteers and workers, also need to be addressed in ensuring seamless SHSCM.

\subsection{Selecting the Best Strategy}

The overall dominance of the strategies under consideration for tackling COVID19 is given in Table 5. From Table 5, it is observed that the strategy S1 (public-private partnership) secured the highest dominance over S2 (private) and S3 (government). The results indicate that the collaboration between public and private sectors can effectively manage the situation in such unprecedented circumstances. This was supported by Park and Chung's (2020) [71] study, indicating that such collaboration would accelerate the speed of relief activities. The finding seems obvious, as such partnerships between public and private compensate for each other's shortcomings [72]. One factor that affirms the vitality of such collaboration is the supply chain network. The private sector efficiently manages the supply chain network, which relies on the transportation sector. During the COVID-19 pandemic situation, the roadway and airway transportation modes are more effective than railways. Hence, the ideal choice is the private sector's engagement in transporting emergency and relief supplies. Further, many NGOs have profound experience in working under similar conditions. Many NGOs are actively involved in relief activities during earthquakes, forest fires, war-affected zones, and tsunamis [73]. The strategy S2 would not be effective in this situation. When private sectors are allowed to handle the situation single handedly, some may choose to take advantage of the situation, and with profit in mind, the private sector may charge excessive rates for the remedies [74]. Hence, the option 
of complete privatization has been ruled out. While the strategy S3 is considered, the government alone cannot manage the situation. Handling the COVID-19 situation requires multitasking activities and multiple players. At the organizing and guidance level, the government may perform efficiently. However, in executing the formulated policies, the government needs assistance. In such a situation, the NGOs involved in similar activities share their knowledge about handling the situation. Therefore, a combined public and private partnership in addressing COVID-19 would yield good results [75]. Hence, the study suggests a public-private partnership as the most effective strategy in SHSCM.

\subsection{Implications of the Study}

The unprecedented COVID-19 pandemic has raised a question about the preparedness of global countries in ensuring medical facilities and in responding to emergency medical needs. The COVID-19 pandemic has created doubt whether the sustainable development goals (SDGs), originally framed for leveraging the living standard of people, are fit for postpandemic conditions. In particular, the COVID-19 pandemic has created great concern about SDG 3 (good health and wellbeing). Although SDGs were the outcome of dialogues held among the global countries, the implementation of the SDGs requires a different strategy for each country. Misinformation has been a paramount challenge in controlling the spread of COVID-19. In controlling the spread of misinformation and debunking false information, various global bodies have engaged themselves in providing a credible source of information. For instance, the WHO maintains an online public page titled "myth buster" which clarifies doubts regarding COVID-19 [76]. To create awareness among the public on medical-related myths and misbeliefs, developing health literacy among the public should be the primary goal. Such an initiative would be useful in meeting future health challenges. As the emergence of new clusters has been identified as a major problem in containing the spread of COVID-19, enforcement of common rules would be useful. Further, ensuring the supply of essential medical supplies is also critical. During this pandemic situation, it has been identified that most of the developed countries are stocking more medical essentials than they need [77]. Such overstocking affects the fair distribution of medical essentials, especially in this pandemic situation. As a result of overstocking medical essentials, developing countries are going to be affected in the worst manner [78]. Overstocking by developed countries raises a question about SDG 17 (partnerships for the goals). In a pandemic situation, the goal is to control and eliminate COVID-19. Hence, to ensure fair distribution of medical essentials, a universal framework must be developed, and the developed nations must help the developing nations in containing the spread of COVID-19 [79]. It is important to develop the sustainable supply, manufacturing, and distribution of medical goods to ensure sustainability in the supply chain during and after the COVID-19 pandemic era [76].

\section{Conclusions}

This study attempted to identify, analyze, and evaluate the challenges to SHSCM concerning the COVID-19 pandemic situation. Accordingly, 20 challenges falling under five categories were identified through a literature review and discussion with 10 experts. A questionnaire-based response was obtained from the experts to ascertain the appropriateness of the challenges identified. Then, a neutrosophic AHP was used to calculate the weight of the challenges. Finally, a neutrosophic TODIM was used to rank the strategies. The study's findings reveal that facility location problems, short lead time for emergency supplies, the spread of rumors, the rapid emergence of new clusters, and doubt concerning the available remedy are five critical challenges of SHSCM during COVID-19. Additionally, the study suggests public-private partnership as a possible and efficient strategy in tackling the COVID-19 situation.

This study makes some significant contributions. In this study, a concrete and reliable framework was proposed to help industry practitioners overcome SHSCM challenges. This study is specifically important for government agencies and pharmaceutical organizations in carrying out SHSCM without any difficulty. The challenges considered and discussed in 
this study give sufficient information to the parties involved in SHSCM. Furthermore, the challenges considered in the study were categorized under five categories of sustainability. With this information, it is easy for the parties involved in SHSCM to identify the category that needs more attention, and they may take appropriate steps to eliminate the challenges at the earliest stage. As this study was carried out in India, a developing country, the outcome of the study can serve as a vital guide to coordinate SHSCM activities in other developing countries.

Despite its contributions and implications, this study has some limitations. The challenges identified in this study depend on literature reviews and expert opinions. Furthermore, the challenges categorized in the study are based on expert feedback and, specifically, on Indian expert feedback; hence, this study's outcome may not be generalized globally. Second, only the weight of the challenges was calculated in the study using neutrosophic AHP. These drawbacks pave the way for future research. In the future, more challenges may be identified through a focused study, and similar work may be carried out in a cross-country study. A study revealing their interrelationships would reveal the nature of the challenges. Such studies may assist in overcoming these limitations.

Author Contributions: Conceptualization, K.K. and B.S.; methodology, K.K.; software, K.K.; validation, B.S., S.M.A., and S.K.P.; formal analysis, B.S.; investigation, B.S.; resources, B.S., S.M.A., and S.K.P.; data curation, K.K.; writing-original draft preparation, B.S. and K.K.; writing-review and editing, S.M.A. and K.K.; visualization, B.S.; supervision, S.M.A.; project administration, S.K.P. All authors have read and agreed to the published version of the manuscript.

Funding: This research received no external funding.

Institutional Review Board Statement: Not applicable.

Informed Consent Statement: Informed consent was obtained from all subjects involved in the study.

Data Availability Statement: Not Applicable.

Acknowledgments: We would like to thank the anonymous reviewers for their comments that allowed to further enhance the outcome of this research.

Conflicts of Interest: The authors declare no conflict of interest.

\section{Appendix A}

Table A1. Questionnaire given to the experts.

Challenges
Lack of skilled volunteers and workers
Change of the head of the monitoring committee
Lack of coordination
Lack of division of works
Lack of experts for pandemic management
Doubt concerning the available remedy
Lack of awareness among people
Spread of rumors
Influence of socioeconomic and political condition of the rion
Limited information and telecommunication infrastructure
Inadequate transport infrastructure
Poor adoption of technologies
Short lead time for emergency supplies
Insufficient funds in handling the pandemic
Facility location problem
Nonavailability of suitable transport infrastructure
Shortage of precautionary materials
Uncertainty in demand
Rapid emergence of new clusters
Communication barriers (i.e., different languages and cultures)


Table A2. Pairwise comparison of the challenges.

\begin{tabular}{|c|c|c|c|c|c|c|c|c|c|c|c|c|c|c|c|c|c|c|c|c|}
\hline & C11 & C12 & C13 & C14 & C15 & $\mathrm{C} 21$ & $\mathrm{C} 22$ & $\mathrm{C} 23$ & $\mathrm{C} 24$ & C31 & C32 & C33 & C34 & C41 & C42 & C43 & C44 & C51 & C52 & C53 \\
\hline C11 & $\mathrm{N}$ & A & $S$ & L & A & $\mathrm{A}$ & $S$ & $S$ & $\mathrm{~L}$ & $\mathrm{~L}$ & $\mathrm{~L}$ & $S$ & $S$ & $\mathrm{~A}$ & $\mathrm{~A}$ & A & $S$ & $S$ & $S$ & $\mathrm{~S}$ \\
\hline C12 & $\mathrm{V}$ & $\mathrm{N}$ & $\mathrm{S}$ & $\mathrm{V}$ & $S$ & $S$ & $\mathrm{~V}$ & $S$ & $\mathrm{~V}$ & A & $\mathrm{V}$ & $\mathrm{S}$ & $\mathrm{S}$ & $\mathrm{V}$ & $\mathrm{V}$ & $S$ & $\mathrm{~V}$ & $\mathrm{~S}$ & S & $\mathrm{V}$ \\
\hline C13 & S & V & $\mathrm{N}$ & S & A & $\mathrm{L}$ & $\mathrm{L}$ & A & $\mathrm{A}$ & L & A & $\mathrm{V}$ & $\mathrm{S}$ & S & $\mathrm{L}$ & A & A & $\mathrm{S}$ & S & $\mathrm{A}$ \\
\hline C14 & A & $S$ & L & $\mathrm{N}$ & A & $S$ & $S$ & S & V & $S$ & V & V & $S$ & $S$ & $\overline{\mathrm{L}}$ & A & A & A & $S$ & $\mathrm{~S}$ \\
\hline C15 & V & V & V & V & $\mathrm{N}$ & A & $S$ & S & S & $\mathrm{V}$ & V & V & $S$ & $\mathrm{~V}$ & $\mathrm{~V}$ & S & S & S & $\mathrm{A}$ & $\mathrm{S}$ \\
\hline C21 & $\mathrm{V}$ & $S$ & V & V & S & $\mathrm{N}$ & V & $\mathrm{V}$ & S & S & $S$ & V & $\mathrm{V}$ & $\mathrm{V}$ & $\mathrm{V}$ & $S$ & $S$ & $S$ & $\mathrm{~S}$ & $\mathrm{~V}$ \\
\hline C22 & $\mathrm{V}$ & $\mathrm{V}$ & $\mathrm{S}$ & $\mathrm{S}$ & $\mathrm{V}$ & $\mathrm{V}$ & $\mathrm{N}$ & $\mathrm{V}$ & $\mathrm{V}$ & $S$ & $\mathrm{~S}$ & A & A & $\mathrm{A}$ & $\mathrm{A}$ & $\mathrm{L}$ & L & $\mathrm{L}$ & S & $\mathrm{A}$ \\
\hline $\mathrm{C} 23$ & $S$ & A & $\mathrm{S}$ & A & A & $S$ & $S$ & $\mathrm{~N}$ & $\mathrm{~A}$ & $\mathrm{~S}$ & $\mathrm{~S}$ & A & S & S & S & A & A & A & A & $\mathrm{S}$ \\
\hline C24 & $\mathrm{V}$ & $\mathrm{V}$ & $\mathrm{V}$ & $\mathrm{V}$ & V & $S$ & $S$ & $S$ & $\mathrm{~N}$ & $\mathrm{~V}$ & $\mathrm{~V}$ & $\mathrm{~V}$ & $\mathrm{~V}$ & $S$ & $\mathrm{~V}$ & $\mathrm{~V}$ & V & $\mathrm{S}$ & $\mathrm{V}$ & $\mathrm{S}$ \\
\hline C 31 & $\mathrm{~S}$ & S & A & A & A & A & $\mathrm{L}$ & $\mathrm{L}$ & A & $\mathrm{N}$ & A & A & $\mathrm{S}$ & S & $\mathrm{A}$ & A & $\mathrm{L}$ & $\mathrm{A}$ & $\mathrm{L}$ & $\mathrm{A}$ \\
\hline C 32 & $\mathrm{~S}$ & $\mathrm{~S}$ & A & A & L & A & $\mathrm{L}$ & A & L & A & $\mathrm{N}$ & V & V & A & $\mathrm{V}$ & S & $\mathrm{V}$ & A & A & $\mathrm{L}$ \\
\hline C 33 & $\mathrm{~V}$ & $\mathrm{~V}$ & V & V & $\mathrm{S}$ & V & $\mathrm{V}$ & $S$ & $\mathrm{~V}$ & S & V & $\mathrm{N}$ & $\mathrm{V}$ & $\mathrm{V}$ & $\mathrm{V}$ & V & $S$ & S & $\mathrm{V}$ & $\mathrm{S}$ \\
\hline C 34 & $S$ & $\mathrm{~V}$ & $S$ & $S$ & $\mathrm{~L}$ & A & L & A & $\mathrm{L}$ & $S$ & L & S & $\mathrm{N}$ & $\mathrm{A}$ & $\mathrm{S}$ & $S$ & L & $S$ & $\mathrm{~L}$ & $\mathrm{~S}$ \\
\hline C41 & $\mathrm{S}$ & S & S & $\mathrm{V}$ & $\mathrm{V}$ & $\begin{array}{l}\mathrm{H} \\
\mathrm{V}\end{array}$ & $\mathrm{V}$ & S & $\mathrm{S}$ & S & $\mathrm{L}$ & S & S & $\mathrm{N}$ & $\mathrm{A}$ & A & S & S & $\mathrm{V}$ & $\mathrm{V}$ \\
\hline C42 & S & $\mathrm{V}$ & $S$ & $\mathrm{~V}$ & V & V & V & V & $S$ & $S$ & $\mathrm{~V}$ & $S$ & $\mathrm{~V}$ & $\mathrm{~S}$ & $\mathrm{~N}$ & V & $\mathrm{V}$ & $\mathrm{V}$ & $\mathrm{V}$ & $\mathrm{V}$ \\
\hline C43 & $\mathrm{s}$ & $\mathrm{V}$ & $\mathrm{A}$ & $\mathrm{A}$ & $\mathrm{L}$ & $\mathrm{L}$ & A & A & $\mathrm{L}$ & $\mathrm{L}$ & A & A & $\mathrm{L}$ & $\mathrm{A}$ & L & $\mathrm{N}$ & L & A & $\mathrm{L}$ & A \\
\hline C44 & $\mathrm{A}$ & $S$ & A & $S$ & $S$ & $\mathrm{~L}$ & A & L & $\mathrm{S}$ & A & L & A & $S$ & $\mathrm{~L}$ & $\bar{S}$ & A & $\mathrm{N}$ & L & $\mathrm{A}$ & $S$ \\
\hline C51 & $S$ & $S$ & A & A & $\mathrm{L}$ & A & L & $S$ & $\mathrm{~L}$ & A & L & A & $\mathrm{L}$ & $\mathrm{A}$ & $\mathrm{A}$ & A & L & $\mathrm{N}$ & $\mathrm{A}$ & $\mathrm{A}$ \\
\hline C52 & $\mathrm{V}$ & $\mathrm{V}$ & S & V & $\mathrm{S}$ & V & $\mathrm{V}$ & $S$ & $\mathrm{~V}$ & V & $\mathrm{S}$ & V & $\mathrm{V}$ & S & $\mathrm{V}$ & S & $\mathrm{V}$ & V & $\mathrm{N}$ & $\mathrm{V}$ \\
\hline C53 & $\mathrm{S}$ & $\mathrm{V}$ & A & S & $\mathrm{L}$ & $\mathrm{A}$ & $\mathrm{L}$ & A & S & $\mathrm{L}$ & A & S & $\mathrm{L}$ & $\mathrm{A}$ & $\mathrm{S}$ & A & $\mathrm{L}$ & A & $\mathrm{S}$ & $\mathrm{N}$ \\
\hline
\end{tabular}

Table A3. The crisp comparison matrix of the challenges.

\begin{tabular}{|c|c|c|c|c|c|c|c|c|c|c|c|c|c|c|c|c|c|c|c|c|}
\hline & C11 & C12 & C13 & C14 & C15 & C21 & C22 & C23 & C24 & C31 & C32 & C33 & C34 & C41 & C42 & C43 & C44 & C51 & C52 & C53 \\
\hline C11 & 1 & 3 & 4 & 1 & 3 & 3 & 4 & 4 & 1 & 1 & 1 & 4 & 4 & 3 & 3 & 3 & 4 & 4 & 4 & 4 \\
\hline C12 & 7 & 1 & 4 & 7 & 4 & 4 & 7 & 4 & 7 & 3 & 7 & 4 & 4 & 7 & 7 & 4 & 7 & 4 & 4 & 7 \\
\hline C13 & 4 & 7 & 1 & 4 & 3 & 1 & 1 & 3 & 3 & 1 & 3 & 7 & 4 & 4 & 1 & 3 & 3 & 4 & 4 & 3 \\
\hline C14 & 3 & 4 & 1 & 1 & 3 & 4 & 4 & 4 & 7 & 4 & 7 & 7 & 4 & 4 & 1 & 3 & 3 & 3 & 4 & 4 \\
\hline C15 & 7 & 7 & 7 & 7 & 1 & 3 & 4 & 4 & 4 & 7 & 7 & 7 & 4 & 7 & 7 & 4 & 4 & 4 & 3 & 4 \\
\hline C21 & 7 & 4 & 7 & 7 & 4 & 1 & 7 & 7 & 4 & 4 & 4 & 7 & 7 & 7 & 7 & 4 & 4 & 4 & 4 & 7 \\
\hline C22 & 7 & 7 & 4 & 4 & 7 & 7 & 1 & 7 & 7 & 4 & 4 & 3 & 3 & 3 & 3 & 1 & 1 & 1 & 4 & 3 \\
\hline C23 & 4 & 3 & 4 & 3 & 3 & 4 & 4 & 1 & 3 & 4 & 4 & 3 & 4 & 4 & 4 & 3 & 3 & 3 & 3 & 4 \\
\hline C24 & 7 & 7 & 7 & 7 & 7 & 4 & 4 & 4 & 1 & 7 & 7 & 7 & 7 & 4 & 7 & 7 & 7 & 4 & 7 & 4 \\
\hline C31 & 4 & 4 & 3 & 3 & 3 & 3 & 1 & 1 & 3 & 1 & 3 & 3 & 4 & 4 & 3 & 3 & 1 & 3 & 1 & 3 \\
\hline C 32 & 4 & 4 & 3 & 3 & 1 & 3 & 1 & 3 & 1 & 3 & 1 & 7 & 7 & 3 & 7 & 4 & 7 & 3 & 3 & 1 \\
\hline C 33 & 7 & 7 & 7 & 7 & 4 & 7 & 7 & 4 & 7 & 4 & 7 & 1 & 7 & 7 & 7 & 7 & 4 & 4 & 7 & 4 \\
\hline C34 & 4 & 7 & 4 & 4 & 1 & 3 & 1 & 3 & 1 & 4 & 1 & 4 & 1 & 3 & 4 & 4 & 1 & 4 & 1 & 4 \\
\hline C41 & 4 & 4 & 4 & 7 & 7 & 7 & 7 & 4 & 4 & 4 & 1 & 4 & 4 & 1 & 3 & 3 & 4 & 4 & 7 & 7 \\
\hline C42 & 4 & 7 & 4 & 7 & 7 & 7 & 7 & 7 & 4 & 4 & 7 & 4 & 7 & 4 & 1 & 7 & 7 & 7 & 7 & 7 \\
\hline C43 & 4 & 7 & 3 & 3 & 1 & 1 & 3 & 3 & 1 & 1 & 3 & 3 & 1 & 3 & 1 & 1 & 1 & 3 & 1 & 3 \\
\hline C44 & 3 & 4 & 3 & 4 & 4 & 1 & 3 & 1 & 4 & 3 & 1 & 3 & 4 & 1 & 4 & 3 & 1 & 1 & 3 & 4 \\
\hline C51 & 4 & 4 & 3 & 3 & 1 & 3 & 1 & 4 & 1 & 3 & 1 & 3 & 1 & 3 & 3 & 3 & 1 & 1 & 3 & 3 \\
\hline C52 & 7 & 7 & 4 & 7 & 4 & 7 & 7 & 4 & 7 & 7 & 4 & 7 & 7 & 4 & 7 & 4 & 7 & 7 & 1 & 7 \\
\hline C53 & 4 & 7 & 3 & 4 & 1 & 3 & 1 & 3 & 4 & 1 & 3 & 4 & 1 & 3 & 4 & 3 & 1 & 3 & 4 & 1 \\
\hline
\end{tabular}

Table 4. The normalized comparison matrix of the category.

\begin{tabular}{|c|c|c|c|c|c|c|c|c|c|c|c|c|c|c|c|c|c|c|c|c|}
\hline & C11 & 12 & $\mathrm{C} 13$ & 14 & 15 & C21 & 22 & $\mathrm{C} 23$ & $\mathrm{C} 24$ & C31 & 32 & C33 & C34 & C41 & $\mathrm{C} 42$ & $\mathrm{C} 43$ & C44 & C51 & C52 & C53 \\
\hline C11 & 0 & J3 & 05 & 01 & 04 & 0 & US & 0 & 0.0 & 0.01 & .0 & 0.04 & 0.05 & 0.04 & 0.04 & 0.04 & & 0.06 & & J.0S \\
\hline C12 & & & & & 06 & & & & & & 00 & & & 0.09 & & 0.05 & 0 & 0.06 & 05 & 0.08 \\
\hline $\mathrm{C} 13$ & & 07 & & & 04 & & 01 & 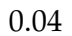 & & 001 & 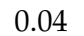 & 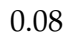 & 0.05 & 0 & & .04 & 4 & 56 & .05 & 0.04 \\
\hline $\mathrm{C} 14$ & & & & & & & & $0-$ & & & 0 & & & 15 & & & & & & 05 \\
\hline C15 & 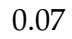 & 07 & 0.09 & & 0.01 & 0.04 & 0.05 & 0.05 & 0.05 & 0.10 & 0.09 & 0.08 & 0.05 & 0.09 & 0.08 & 0.05 & .06 & 0.06 & 04 & 0.05 \\
\hline C21 & 07 & 0.04 & 0.09 & 08 & 0.06 & 0.01 & 0.09 & 0.09 & 0.05 & 0.06 & 0.05 & 0.08 & 0.08 & .09 & 0.08 & 0.05 & .06 & 0.06 & .05 & 0.08 \\
\hline $\mathrm{C} 22$ & & & & & .10 & & & 0 & & & & & 0.04 & & & 01 & & 01 & 5 & 0.04 \\
\hline $\mathrm{C} 23$ & & 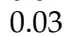 & & & 0.04 & & & 0.0 & & & 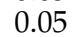 & & 0.05 & & & .04 & & 0.04 & .04 & 0.05 \\
\hline C24 & 0 & 0.07 & 0.09 & 0 & 0.10 & 0.05 & 0.05 & 0.05 & 0.01 & 0.10 & 0.09 & 0.08 & 0.08 & 5 & 0.08 & 0.09 & & 0.06 & 09 & 0.05 \\
\hline (C)1 & & & & & & & & & & & & 0.03 & & & & 4 & & 04 & 1 & 0.04 \\
\hline C32 & & & & & & & & & & & & & & & & - & & 0.04 & 4 & 0.01 \\
\hline C33 & n & 07 & 0.09 & & 0.06 & 0.09 & 0. & 0.0 & 0.09 & 0.06 & 0.09 & 0.01 & 0.08 & 0.0 & 0.08 & 0.09 & & 0.06 & 9 & 0.05 \\
\hline & & & & & & & & & & & & & & & & & & & & 0.05 \\
\hline C & & & & & & & & & & & 0 & & & & 0. & \pm & & 0.06 & 9 & 0.08 \\
\hline C42 & & U/ & & 0.08 & 0.1 & 0.0 & 0. & 0.09 & 0.05 & 0.06 & 0.0 & & 0.08 & 0.0 & 0.01 & 0.09 & & 0.10 & 0.09 & 0.08 \\
\hline C43 & $0 \Omega$ & 0.07 & 0.04 & & 0.01 & 0.01 & 0.04 & 0.04 & 0.01 & 0.01 & 0.04 & 0.03 & 0.01 & 0.04 & 0.01 & 0.01 & 1 & 0.04 & 0.01 & 0.04 \\
\hline$C \longrightarrow$ & & & & & & & & & & 0. & & 0. & & & & & & 0.01 & & 0.05 \\
\hline C & & & & & & & & & & & & & & & & & & 0.01 & & 0.04 \\
\hline C52 & 0 & 0.07 & 0.05 & 0.0 & 0.0 & 0.0 & 0.09 & 0.0 & 0.09 & 0.10 & 0.05 & 0.08 & 0.08 & 0.05 & & 0.05 & & 0.10 & 0.01 & 0.08 \\
\hline C53 & 0.04 & 0.07 & 0.04 & 0.04 & 0.01 & 0.04 & 0.01 & 0.04 & 0.05 & 0.01 & 0.04 & 0.04 & 0.01 & 0.04 & 0.05 & 0.04 & 0.01 & 0.04 & 0.05 & 0.01 \\
\hline
\end{tabular}




\section{Appendix B}

Table A5. Comparison of challenges and strategies.

\begin{tabular}{ccccccccccccccccccccc}
\hline & C11 & C12 & C13 & C14 & C15 & C21 & C22 & C23 & C24 & C31 & C32 & C33 & C34 & C41 & C42 & C43 & C44 & C51 & C52 & C53 \\
\hline C11 & S & V & A & S & A & V & S & S & A & A & N & A & S & V & V & V & S & V & A & S \\
C12 & V & S & S & A & A & N & A & A & A & S & S & A & A & A & S & S & A & A & S & S \\
C13 & V & V & V & V & V & S & S & A & S & S & V & S & V & A & S & V & S & V & S & V \\
\hline
\end{tabular}

Table A6. Crisp matrix.

\begin{tabular}{ccccccccccccccccccccc}
\hline & C11 & C12 & C13 & C14 & C15 & C21 & C22 & C23 & C24 & C31 & C32 & C33 & C34 & C41 & C42 & C43 & C44 & C51 & C52 & C53 \\
\hline C11 & 4 & 7 & 3 & 4 & 3 & 7 & 4 & 4 & 3 & 3 & 1 & 3 & 4 & 7 & 7 & 7 & 4 & 7 & 3 & 4 \\
C12 & 7 & 4 & 4 & 3 & 3 & 1 & 3 & 3 & 3 & 4 & 4 & 3 & 3 & 3 & 4 & 4 & 3 & 3 & 4 & 4 \\
C13 & 7 & 7 & 7 & 7 & 7 & 4 & 4 & 3 & 4 & 4 & 7 & 4 & 7 & 3 & 4 & 7 & 4 & 7 & 4 & 7 \\
\hline
\end{tabular}

Table A7. Normalized decision matrix.

\begin{tabular}{lllllllllllllllllllll}
\hline & C11 & C12 & C13 & C14 & C15 & C21 & C22 & C23 & C24 & C31 & C32 & C33 & C34 & C41 & C42 & C43 & C44 & C51 & C52 & C53 \\
\hline C11 & 0.22 & 0.39 & 0.21 & 0.29 & 0.23 & 0.58 & 0.36 & 0.40 & 0.30 & 0.27 & 0.08 & 0.30 & 0.29 & 0.54 & 0.47 & 0.39 & 0.36 & 0.41 & 0.27 & 0.27 \\
C12 & 0.39 & 0.22 & 0.29 & 0.21 & 0.23 & 0.08 & 0.27 & 0.30 & 0.30 & 0.36 & 0.33 & 0.30 & 0.21 & 0.23 & 0.27 & 0.22 & 0.27 & 0.18 & 0.36 & 0.27 \\
C13 & 0.39 & 0.39 & 0.50 & 0.50 & 0.54 & 0.33 & 0.36 & 0.30 & 0.40 & 0.36 & 0.58 & 0.40 & 0.50 & 0.23 & 0.27 & 0.39 & 0.36 & 0.41 & 0.36 & 0.47 \\
\hline
\end{tabular}

Appendix C

Table A8. Dominance degree of strategy 1.

\begin{tabular}{cccccccccccccccccccccc}
\hline & C11 & C12 & C13 & C14 & C15 & C21 & C22 & C23 & C24 & C31 & C32 & C33 & C34 & C41 & C42 & C43 & C44 & C51 & C52 & C53 \\
\hline (A1, A2) & -0.08 & 0.10 & -0.06 & 0.06 & 0 & 0.18 & 0.07 & 0.06 & 0 & -0.05 & -0.1 & 0 & 0.05 & 0.13 & 0.12 & 0.07 & 0.05 & 0.08 & -0.08 & 0 \\
(A1, A3) & -0.08 & 0.00 & -0.11 & -0.10 & -0.12 & 0.13 & 0 & 0.06 & -0.08 & -0.05 & 0.15 & -0.08 & -0.08 & 0.13 & 0.12 & 0 & 0 & 0 & -0.08 & -0.08 \\
\hline
\end{tabular}

Table A9. Dominance degree of strategy 2.

\begin{tabular}{lccccccccccccccccccccc}
\hline & C11 & C12 & C13 & C14 & C15 & C21 & C22 & C23 & C24 & C31 & C32 & C33 & C34 & C41 & C42 & C43 & C44 & C51 & C52 & C53 \\
\hline (A2, A1) & 0.81 & -1.61 & 0.05 & -1.29 & 0 & -2.74 & -1.34 & -1.52 & 0 & 0.05 & 0.10 & 0 & -1.48 & -2.33 & -1.64 & -2.46 & -1.62 & -2.75 & 0.07 & 0 \\
(A2, A3) & 0 & -1.61 & -2.31 & -2.46 & -2.22 & -1.94 & -1.34 & 0 & -1.17 & 0 & -2.41 & -1.17 & -2.83 & 0 & 0 & -2.46 & -1.62 & -2.75 & 0 & -2.37 \\
\hline
\end{tabular}

Table A10. Dominance degree of strategy 3.

\begin{tabular}{ccccccccccccccccccccccc}
\hline & C11 & C12 & C13 & C14 & C15 & C21 & C22 & C23 & C24 & C31 & C32 & C33 & C34 & C41 & C42 & C43 & C44 & C51 & C52 & C53 \\
\hline (A3, A1) & 0.81 & 0 & 0.10 & 0.10 & 0.13 & -1.94 & 0 & -1.52 & 0.08 & 0.05 & 0.14 & 0.08 & 0.08 & -2.33 & -1.64 & 0 & 0 & 0 & 0.08 & 0.08 \\
(A3, A2) & 0 & 0.10 & 0.09 & 0.11 & 0.13 & 0.12 & 0.06 & 0 & 0.08 & 0 & 0.10 & 0.08 & 0.10 & 0 & 0 & 0.06 & 0.05 & 0.08 & 0 & 0.08 &
\end{tabular}

\section{References}

1. Maqbool, A.; Khan, N.Z. Analyzing barriers for implementation of public health and social measures to prevent the transmission of COVID-19 disease using DEMATEL method. Diabetes Metab. Syndr. Clin. Res. Rev. 2020, 14, 887-892. [CrossRef]

2. Sharma, M.; Luthra, S.; Joshi, S.; Kumar, A. Developing a framework for enhancing survivability of sustainable supply chains during and post-COVID-19 pandemic. Int. J. Logist. Res. Appl. 2020, 1-21. [CrossRef]

3. Balcik, B.; Beamon, B.M.; Krejci, C.C.; Muramatsu, K.M.; Ramirez, M. Coordination in humanitarian relief chains: Practices, challenges and opportunities. Int. J. Prod. Econ. 2010, 126, 22-34. [CrossRef]

4. Behl, A.; Dutta, P. Humanitarian supply chain management: A thematic literature review and future directions of research. Ann. Oper. Res. 2019, 283, 1001-1044. [CrossRef]

5. Lu, Z.; Gao, Y.; Zhao, W. A TODIM-based approach for environmental impact assessment of pumped hydro energy storage plant. J. Clean. Prod. 2020, 248, 119265. [CrossRef]

6. Sabri, Y.; Zarei, M.H.; Harland, C. Using collaborative research methodologies in humanitarian supply chains. J. Humanit. Logist. Supply Chain Manag. 2019, 9, 371-409. [CrossRef]

7. Vega, D. Case studies in humanitarian logistics research. J. Humanit. Logist. Supply Chain Manag. 2018, 8, 134-152. [CrossRef]

8. Turrini, L.; Besiou, M.; Papies, D.; Meissner, J. The role of operational expenditures and misalignments in fundraising for international humanitarian aid. J. Oper. Manag. 2020, 66, 379-417. [CrossRef] 
9. Ozdemir, A.I.; Erol, I.; Ar, I.M.; Peker, I.; Asgary, A.; Medeni, T.D.; Medeni, I.T. The role of blockchain in reducing the impact of barriers to humanitarian supply chain management. Int. J. Logist. Manag. 2020. Ahead of printing. [CrossRef]

10. Dubey, R.; Gunasekaran, A.; Childe, S.J.; Roubaud, D.; Wamba, S.; Giannakis, M.; Foropon, C. Big data analytics and organizational culture as complements to swift trust and collaborative performance in the humanitarian supply chain. Int. J. Prod. Econ. 2019, 210, 120-136. [CrossRef]

11. Prasad, S.; Zakaria, R.; Altay, N. Big data in humanitarian supply chain networks: A resource dependence perspective. Ann. Oper. Res. 2018, 270, 383-413. [CrossRef]

12. Queiroz, M.M.; Wamba, S.; De Bourmont, M.; Telles, R. Blockchain adoption in operations and supply chain management: Empirical evidence from an emerging economy. Int. J. Prod. Res. 2020, 1-17. [CrossRef]

13. Smarandache, F. Neutrosophic set-A generalization of the intuitionistic fuzzy set. Int. J. Pure Appl. Math. 2005, $24,287-297$.

14. Gomes, L.F.A.M.; Lima, M.M.P.P. TODIM: Basics and application to multicriteria ranking of projects with environmental impacts. Found. Comput. Decis. Sci. 1992, 16, 113-127.

15. Kazancoglu, Y.; Burmaoglu, S. ERP software selection with MCDM: Application of TODIM method. Int. J. Bus. Inf. Syst. 2013, 13, 435. [CrossRef]

16. Huang, S.-H.S.; Hsu, W.-K.K.; Chen, J.-W. A safety evaluation system based on a revised fuzzy AHP for dangerous goods in airfreights. J. Transp. Saf. Secur. 2020, 12, 611-627. [CrossRef]

17. Wang, J.; Dou, R.; Muddada, R.R.; Zhang, W. Management of a holistic supply chain network for proactive resilience: Theory and case study. Comput. Ind. Eng. 2018, 125, 668-677. [CrossRef]

18. Nagurney, A.; Qiang, Q. Quantifying supply chain network synergy for humanitarian organizations. IBM J. Res. Dev. 2020, 64, 12:1-12:16. [CrossRef]

19. UNDER. Available online: https:/ / www.undrr.org/ (accessed on 18 January 2021).

20. IFRC. Available online: https:/ / www.ifrc.org/ (accessed on 18 January 2021).

21. Nayak, R.; Choudhary, S. Operational excellence in humanitarian logistics and supply chain management through leagile framework: A case study from a non-mature economy. Prod. Plan. Control 2020, 1-16. [CrossRef]

22. John, L.; Gurumurthy, A.; Soni, G.; Jain, V. Modelling the inter-relationship between factors affecting coordination in a humanitarian supply chain: A case of Chennai flood relief. Ann. Oper. Res. 2019, 283, 1227-1258. [CrossRef]

23. Gossler, T.; Wakolbinger, T.; Burkart, C. Outsourcing in humanitarian logistics-Status quo and future directions. Int. J. Phys. Distrib. Logist. Manag. 2020, 50, 403-438. [CrossRef]

24. Ghorbani, M.; Ramezanian, R. Integration of carrier selection and supplier selection problem in humanitarian logistics. Comput. Ind. Eng. 2020, 144, 106473. [CrossRef]

25. Dubey, R.; Bryde, D.J.; Foropon, C.; Graham, G.; Giannakis, M.; Mishra, D.B. Agility in humanitarian supply chain: An organizational information processing perspective and relational view. Ann. Oper. Res. 2020. [CrossRef] [PubMed]

26. Fosso Wamba, S. Humanitarian supply chain: A bibliometric analysis and future research directions. Ann. Oper. Res. 2020. [CrossRef]

27. Chen, J.; Wang, P.; Zhou, J.; Song, M.; Zhang, X. Influencing factors and efficiency of funds in humanitarian supply chains: The case of Chinese rural minimum living security funds. Ann. Oper. Res. 2020. [CrossRef]

28. Maghfiroh, M.F.N.; Hanaoka, S. Multi-modal relief distribution model for disaster response operations. Prog. Disaster Sci. 2020, 6, 100095. [CrossRef]

29. Wagner, S.M.; Thakur-Weigold, B.; Gatti, F.; Stumpf, J. Measuring and improving the impact of humanitarian logistics consulting. Prod. Plan. Control 2021, 32, 83-103. [CrossRef]

30. Abidi, H.; De Leeuw, S.; Klumpp, M. Measuring Success in Humanitarian Supply Chains. Int. J. Bus. Manag. Invent. 2013, 2, 31-39.

31. Das, L. Role of Humanitarian Supply Chain Management in Various Disaster Situations across the Globe. In Managing Humanitarian Logistics; Springer: Berlin/Heidelberg, Germany, 2016; pp. 253-271.

32. Seifert, L.; Kunz, N.; Gold, S. Humanitarian supply chain management responding to refugees: A literature review. J. Humanit. Logist. Supply Chain Manag. 2018, 8, 398-426. [CrossRef]

33. Ghasemian Sahebi, I.; Arab, A.; Sadeghi Moghadam, M.R. Analyzing the barriers to humanitarian supply chain management: A case study of the Tehran Red Crescent Societies. Int. J. Disaster Risk Reduct. 2017, 24, 232-241. [CrossRef]

34. Hashemi Petrudi, S.H.; Tavana, M.; Abdi, M. A comprehensive framework for analyzing challenges in humanitarian supply chain management: A case study of the Iranian Red Crescent Society. Int. J. Disaster Risk Reduct. 2020, 42, 101340. [CrossRef]

35. Safarpour, H.; Fooladlou, S.; Safi-Keykaleh, M.; Mousavipour, S.; Pirani, D.; Sahebi, A.; Ghodsi, H.; Farahi-Ashtiani, I.; Dehghani, A. Challenges and barriers of humanitarian aid management in 2017 Kermanshah earthquake: A qualitative study. BMC Public Health 2020, 20, 563. [CrossRef] [PubMed]

36. Adobor, H. Supply chain resilience: A multi-level framework. Int. J. Logist. Res. Appl. 2019, 22, 533-556. [CrossRef]

37. Yadav, D.K.; Barve, A. Modeling Post-disaster Challenges of Humanitarian Supply Chains: A TISM Approach. Glob. J. Flex. Syst. Manag. 2016, 17, 321-340. [CrossRef]

38. Huda, M.N.; Islam, R.; Qureshi, M.O.; Pillai, S.; Hossain, S.Z. Rumour and social stigma as barriers to the prevention of coronavirus disease (COVID-19): What solutions to consider? Glob. Biosecur. 2020, 1. [CrossRef] 
39. Sharma, P.; Joshi, A. Challenges of using big data for humanitarian relief: Lessons from the literature. J. Humanit. Logist. Supply Chain Manag. 2019, 10, 423-446. [CrossRef]

40. Qiu, Y.; Gu, D.; Zhang, H.; Tang, H.; Cao, Y. Two-stage matching decision-making method in medical service supply chain. Int. J. Logist. Res. Appl. 2021, 1-16. [CrossRef]

41. Maghsoudi, A.; Zailani, S.; Ramayah, T.; Pazirandeh, A. Coordination of efforts in disaster relief supply chains: The moderating role of resource scarcity and redundancy. Int. J. Logist. Res. Appl. 2018, 21, 407-430. [CrossRef]

42. Agarwal, S.; Kant, R.; Shankar, R. Modeling the enablers of humanitarian supply chain management: A hybrid group decisionmaking approach. Benchmarking An Int. J. 2020. [CrossRef]

43. Agarwal, S.; Kant, R.; Shankar, R. Evaluating solutions to overcome humanitarian supply chain management barriers: A hybrid fuzzy SWARA-Fuzzy WASPAS approach. Int. J. Disaster Risk Reduct. 2020, 51, 101838. [CrossRef]

44. Saaty, T.L. The Analytic Hierarchy Process. In Agricultural Economics Review; Mcgraw Hill: New York, NY, USA, 1980 ; p. 70.

45. Mohammad, M.F.; Rahman, N.A.A.; Hassan, R.; Kurniawan, R. Multi-Criteria Decision Making (MCDM) for bachelor of aircraft engineering technology (avionic) final year students in project management course: AHP method for career selection. J. Eng. Appl. Sci. 2017, 12, 705-714.

46. Majumdar, A.; Hazra, T.; Dutta, A. Landfill Site Selection by AHP Based Multi-criteria Decision Making Tool: A Case Study in Kolkata, India. J. Inst. Eng. Ser. A 2017, 98, 277-283. [CrossRef]

47. Souissi, D.; Zouhri, L.; Hammami, S.; Msaddek, M.H.; Zghibi, A.; Dlala, M. GIS-based MCDM-AHP modeling for flood susceptibility mapping of arid areas, southeastern Tunisia. Geocarto Int. 2020, 35, 991-1017. [CrossRef]

48. Zadeh, L.A. Information and control. Fuzzy Sets 1965, 8, 338-353.

49. Kahraman, C.; Öztayşi, B.; Onar, S.Ç.; Boltürk, E. Neutrosophic AHP and prioritization of legal service outsourcing firms/law offices. In Proceedings of the Data Science and Knowledge Engineering for Sensing Decision Support; WORLD SCIENTIFIC, Ireland, UK, 21-24 August 2018; pp. 1176-1183.

50. Salgado, M.F.S.; Pardo, J.P.C.; Palacios, T.H.C. Application of the Neutrosophic AHP Method for the Development of a Training Project on the Adoption Process in Ecuador. Neutrosophic Sets Syst. 2020, 37, 399-408.

51. Fan, J.; Li, D.; Wu, M. An Extended TODIM Method with Unknown Weight Information under Interval-Valued Neutrosophic Environment for FMEA. Int. J. Comput. Intell. Syst. 2020, 14, 174. [CrossRef]

52. Long, X.; Liu, L.; Xiao, C.; Cheng, P.; Fu, C. Restoration Methods Selection for Wood Components of Chinese Ancient Architectures Based on TODIM with Single-Valued Neutrosophic Sets. Math. Probl. Eng. 2020, 2020, 1-14. [CrossRef]

53. Shareef, M.A.; Dwivedi, Y.K.; Kumar, V.; Hughes, D.L.; Raman, R. Sustainable supply chain for disaster management: Structural dynamics and disruptive risks. Ann. Oper. Res. 2020, 1-25. [CrossRef]

54. Besiou, M.; Van Wassenhove, L.N. Humanitarian Operations: A World of Opportunity for Relevant and Impactful Research. Manuf. Serv. Oper. Manag. 2020, 22, 135-145. [CrossRef]

55. Sreedharan, V.R.; Kek, V.; Dhanya, M.; Anjali, S.; Arunprasad, P. Understanding the role of logistics in humanitarian operations: Key findings and analysis from literatures. Int. J. Logist. Syst. Manag. 2020, 36, 463. [CrossRef]

56. Liu, P.; You, X. Probabilistic linguistic TODIM approach for multiple attribute decision-making. Granul. Comput. 2017, 2, 333-342. [CrossRef]

57. Liu, P.; Teng, F. Probabilistic linguistic TODIM method for selecting products through online product reviews. Inf. Sci. 2019, 485, 441-455. [CrossRef]

58. Alali, F.; Tolga, A.C. Portfolio allocation with the TODIM method. Expert Syst. Appl. 2019, 124, 341-348. [CrossRef]

59. Yin, J.; Guo, J.; Ji, T.; Cai, J.; Xiao, L.; Dong, Z. An extended TODIM method for project manager's competency evaluation. J. Civ. Eng. Manag. 2019, 25, 673-686. [CrossRef]

60. WHO Coronavirus (COVID-19) Dashboard. Available online: https:/ / covid19.who.int/ (accessed on 18 January 2021).

61. Paul, S.K.; Chowdhury, P. Strategies for Managing the Impacts of Disruptions during COVID-19: An Example of Toilet Paper. Glob. J. Flex. Syst. Manag. 2020, 21, 283-293. [CrossRef]

62. Crommelin, D.J.A.; Volkin, D.B.; Hoogendoorn, K.H.; Lubiniecki, A.S.; Jiskoot, W. The Science is There: Key Considerations for Stabilizing Viral Vector-Based Covid-19 Vaccines. J. Pharm. Sci. 2020, 110, 627-634. [CrossRef]

63. Barnes, S.J. Information management research and practice in the post-COVID-19 world. Int. J. Inf. Manag. 2020, 55, 102175. [CrossRef]

64. Queiroz, M.M.; Ivanov, D.; Dolgui, A.; Fosso Wamba, S. Impacts of epidemic outbreaks on supply chains: Mapping a research agenda amid the COVID-19 pandemic through a structured literature review. Ann. Oper. Res. 2020, 1-38. [CrossRef]

65. McMahon, D.E.; Peters, G.A.; Ivers, L.C.; Freeman, E.E. Global resource shortages during COVID-19: Bad news for low-income countries. PLoS Negl. Trop. Dis. 2020, 14, e0008412. [CrossRef]

66. Taqi, H.M.M.; Ahmed, H.N.; Paul, S.; Garshasbi, M.; Ali, S.M.; Kabir, G.; Paul, S.K. Strategies to Manage the Impacts of the COVID-19 Pandemic in the Supply Chain: Implications for Improving Economic and Social Sustainability. Sustainability 2020, 12, 9483. [CrossRef]

67. Thankappan, K. Combating corona virus disease 2019 and comorbidities: The Kerala experience for the first 100 days. Int. J. Noncommun. Dis. 2020, 5, 36. [CrossRef]

68. Kaur, S.P.; Gupta, V. COVID-19 Vaccine: A comprehensive status report. Virus Res. 2020, 288, 198114. [CrossRef] 
69. Bennet, B.M.; Wolf, J.; Laureano, R.; Sellers, R.S. Review of Current Vaccine Development Strategies to Prevent Coronavirus Disease 2019 (COVID-19). Toxicol. Pathol. 2020, 48, 800-809. [CrossRef] [PubMed]

70. Krause, P.; Fleming, T.R.; Longini, I.; Henao-Restrepo, A.M.; Peto, R.; Dean, N.; Halloran, M.; Huang, Y.; Fleming, T.; Gilbert, P.; et al. COVID-19 vaccine trials should seek worthwhile efficacy. Lancet 2020, 396, 741-743. [CrossRef]

71. Park, J.; Chung, E. Learning from past pandemic governance: Early response and Public-Private Partnerships in testing of COVID-19 in South Korea. World Dev. 2021, 137, 105198. [CrossRef]

72. Golechha, M. COVID-19 Containment in Asia's Largest Urban Slum Dharavi-Mumbai, India: Lessons for Policymakers Globally. J. Urban Health 2020, 97, 796-801. [CrossRef] [PubMed]

73. Banks, N.; Schulpen, L.; Brockington, D. New sectoral perspectives on international NGOs: Scale, dynamics and influences. Dev. Pract. 2020, 30, 695-705. [CrossRef]

74. Armstrong, P.; Armstrong, H.; Bourgeault, I. Privatization and COVID-19: A Deadly Combination for Nursing Homes. In Vulnerable: The Law, Policy and Ethics of COVID-19; University of Ottawa Press: Ontario, ON, Canada, 2020; pp. 451-452.

75. Chowdhury, P.; Paul, S.K.; Kaisar, S.; Moktadir, M.A. COVID-19 pandemic related supply chain studies: A systematic review. Transp. Res. Part E Logist. Transp. Rev. 2021, 148, 102271. [CrossRef]

76. Seshaiyer, P.; McNeely, C.L. Challenges and Opportunities from COVID-19 for Global Sustainable Development. World Med. Health Policy 2020, 12, 443-453. [CrossRef]

77. Goniewicz, K.; Khorram-Manesh, A.; Hertelendy, A.J.; Goniewicz, M.; Naylor, K.; Burkle, F.M. Current Response and Management Decisions of the European Union to the COVID-19 Outbreak: A Review. Sustainability 2020, 12, 3838. [CrossRef]

78. Triviño-Cabrera, L.; Chaves-Guerrero, E.I.; Alejo-Lozano, L. The Figure of the Teacher-Prosumer for the Development of an Innovative, Sustainable, and Committed Education in Times of COVID-19. Sustainability 2021, 13, 1128. [CrossRef]

79. Qarnain, S.S.; Sattanathan, M.; Sankaranarayanan, B.; Ali, S.M. Analyzing energy consumption factors during coronavirus (COVID-19) pandemic outbreak: A case study of residential society. Energy Sour. Part A Recover. Util. Environ. Eff. 2020, 1-20. [CrossRef] 